\title{
Parasitic infection levels by Anisakis spp. larvae (Nematoda: Anisakidae) in the black scabbardfish Aphanopus carbo (Osteichthyes: Trichiuridae) from Portuguese waters
}

\author{
CRISTINA CRUZ, AURÉLIA SARAIVA, MARIA JOÃO SANTOS, JORGE C. EIRAS, \\ CARLA VENTURA, JOÃO PAULO SOARES and MARGARIDA HERMIDA
}

Departamento de Zoologia e Antropologia, Faculdade de Ciências, Universidade do Porto, Rua do Campo Alegre, S/N, Edifício FC4, 4169-007 Porto, Portugal. E-mail: cfcruz@fc.up.pt

CIIMAR, Centro Interdisciplinar de Investigação Marinha e Ambiental, Universidade do Porto, Rua dos Bragas, 289, 4050-123 Porto, Portugal.

\begin{abstract}
SUMMARY: Aphanopus carbo, black scabbardfish, specimens from 3 Portuguese regions (the mainland, Madeira and the Azores) during four (mainland and Madeira) or two (Azores) seasons of the year were examined for the presence of Anisakis. All the fish examined ( $\mathrm{n}=287)$ were infected with Anisakis $\mathrm{L}_{3}$ larvae (prevalence $\left.=100 \%\right)$. Significant geographical differences in intensity were found: the Azores showed the lowest mean intensity value (53.7) and Madeira the highest one (253.9). The intensity of infection was positively correlated with the host length in specimens of Sesimbra and Madeira. Significant seasonal differences in intensity were found in the studied regions. The very high values in prevalence and intensity strongly suggest that the consumption of raw or undercooked black scabbard fish is a potential risk for human health.
\end{abstract}

Keywords: Anisakis larvae, Aphanopus carbo, fish, prevalence, intensity, geographical differences, Portugal.

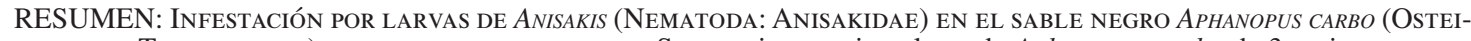
CHTHYES: TRICHIURIDAE) EN AGUAS PORTUGUESAS. - Se examinaron ejemplares de Aphanopus carbo de 3 regiones portuguesas (costa continental, Madeira y Azores) para determinar la presencia de Anisákidos durante cuatro (costa continental y Madeira) o dos (Azores) épocas del año. Todos los ejemplares examinados ( $n=287$ ) estaban infectados por larvas L3 de Anisakis (prevalencia $=100 \%$ ). Se encontraron diferencias geográficas significativas en la intensidad: Azores mostró el valor de intensidad media más bajo (53.7) y Madeira el más alto (253.9). La intensidad de infección mostró una correlación positiva con la talla del huésped en los casos de la costa continental y Madeira. Se encontraron diferencias estacionales significativas en la intensidad en las regiones estudiadas. Los altos valores encontrados en la prevalencia e intensidad sugieren que el consumo de sable negro crudo o medio crudo constituye un riesgo potencial para la salud humana.
\end{abstract}

Palabras clave: larvas de Anisakis, Aphanopus carbo, peces, prevalencia, intensidad, diferencias geograficas, Portugal.

\section{INTRODUCTION}

Nematode larvae of the genus Anisakis Dujardin, 1845 (Nematoda: Anisakidae) are common parasites of marine fish and a potential risk for human health since these larvae can infect humans after the inges- tion of raw or undercooked fish (Ubeira et al., 2000). The larvae, which occur in the body cavity, visceral organs and muscles in live fish, can migrate into flesh after the death of the host (Smith and Wootten, 1975; Silva and Eiras, 2003) and therefore humans are at risk of becoming infected. 
The fish are the intermediate or paratenic hosts of the parasites, whereas marine mammals are the definitive ones. Fish harbouring $\mathrm{L}_{3}$ larvae acquire the infection by feeding on intermediate or paratenic hosts such as crustaceans (euphausiids, copepods and amphipods), fish and cephalopods (Moravec, 1994; Anderson, 2000, Klimpel et al., 2008).

The black scabbardfish, Aphanopus carbo Lowe, 1893 (Osteichthyes: Trichiuridae) is economically a very important fish species that is commonly consumed in Portugal and is highly infected by Anisakis larvae (Costa et al., 1996, 2003; Santos et al., 2009).

In the present work the Anisakis larvae infection of A. carbo sampled in 3 different Portuguese regions (Sesimbra (mainland), and the Madeira and Azores Islands) was studied and the possible geographical and seasonal differences in the parameters of infection and the relationship with fish length were analysed.

\section{MATERIALS AND METHODS}

A total of 287 specimens of Aphanopus carbo were examined for the presence of metazoan parasites. The fish were captured by fishermen in Portuguese waters of the Atlantic Ocean from autumn 2005 to summer 2006. The 3 regions analysed were Sesimbra (Portuguese west continental coast) and the Madeira and Azores Islands (Fig. 1). Samples from Sesimbra and Madeira were obtained in autumn, winter, spring and summer and those from the Azores in autumn and spring.

The fish were transported in ice boxes to the laboratory, where they were placed in individual plastic bags and frozen until further observation. After being defrosted, specimens were identified to confirm that they belonged to A. carbo and not to $A$. intermedius, measured (fork length) and dissected. The body cavity, visceral organs and a small portion of musculature were examined under a stereomicroscope. Any anisakid larvae found were removed, counted and conserved in $70^{\circ}$ alcohol. Larvae identification was made by light microscopy according to structural features after being cleared in glycerine (Berland, 1961; Grabda, 1991; Moravec, 1994).

The prevalence and mean intensity of Anisakis infection were determined for the three sampling sites according to Bush et al. (1997). In addition the mean intensity was determined for each length class

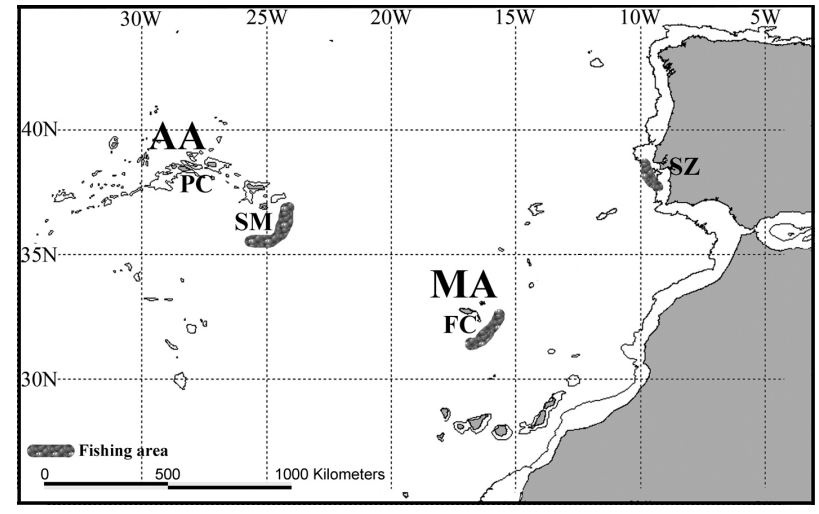

FIG. 1. - Map of the southern northeast Atlantic with the sampling locations of black scabbardfish and the $1000 \mathrm{~m}$ isobath. AA, Azores Archipelago; FC, Funchal; MA, Madeira Archipelago; PC, Pico Island; SM, Santa Maria Island; SZ, Sesimbra (mainland Portugal).

of the host and for each season in the three regions studied.

The significance of the differences in host length among regions and seasons and of the differences in intensity of infection were analysed by Kruskal-Wallis tests (for 3 or more samples) or Mann-Whitney tests (for 2 samples) (Siegel and Castellan, 1989). Whenever significant differences were detected among the 3 regions, analyses between the different pairs of cases were performed by the Mann-Whitney test. The relationship between the intensity of infection and the host length were analysed by Spearman rank correlation (Siegel and Castellan, 1989).

\section{RESULTS}

Anisakis $\mathrm{L}_{3}$ larvae were found in all the fish examined. Their morphological features showed that they belonged to Type I and Type II larvae, as defined by Berland (1961). Some larvae were free in the body cavity, but most of them were encapsulated in all the organs examined (oesophagus, stomach, intestine, intestinal cecae, liver, spleen, gall bladder, swimbladder, gonads and kidney) the stomach being the most infected organ. It is worth mentioning that musculature, although not extensively inspected, also contained some larvae.

The length of fish captured in the 3 regions was significantly different (Table 1). The highest mean length value was found in specimens from Madeira and the lowest in specimens from Sesimbra. There were no significant seasonal variations in fish length from Sesimbra and from Madeira, but significant differences were observed between the seasons in Azores. 
TABLE 1. - Fork length (cm) of Aphanopus carbo examined in the four year seasons: significance of length differences among regions and among seasons estimated by the Kruskal-Wallis $\left(\chi^{2} ; \mathrm{df} ; \mathrm{p}\right)$ or Mann-Whitney $(z ; p)$ test (Sig, significantly different).

\begin{tabular}{|c|c|c|c|c|c|c|c|}
\hline \multirow{2}{*}{$\begin{array}{l}\text { Sampling } \\
\text { Season }\end{array}$} & \multicolumn{3}{|c|}{$\begin{array}{c}\text { Mean length } \pm \text { s.d. } \\
\text { (minimum-maximum) } \\
\text { (number of fish examined) }\end{array}$} & \multirow[t]{2}{*}{$\begin{array}{c}\text { Significance } \\
\text { among the } 3 \text { regions }\end{array}$} & \multicolumn{3}{|c|}{ Significance between regions } \\
\hline & Sesimbra & Madeira & Azores & & Ses/Mad & $\mathrm{Mad} / \mathrm{Az}$ & Ses/Az \\
\hline Autumn & $\begin{array}{c}97.8 \pm 13.4 \\
(70-117) \\
\mathrm{n}=30\end{array}$ & $\begin{array}{c}109.4 \pm 7.5 \\
(93-120) \\
n=30\end{array}$ & $\begin{array}{c}111.9 \pm 5.6 \\
(103-121) \\
\mathrm{n}=26\end{array}$ & $\begin{array}{c}\text { Sig } \\
\chi^{2}=19.543 ; \mathrm{df}=2 \\
\mathrm{p}=0.000\end{array}$ & $\begin{aligned} & \text { Sig } \\
z= & -3.675 \\
p= & 0.000\end{aligned}$ & $\begin{array}{c}\text { Not Sig } \\
z=-0.740 \\
p=0.459\end{array}$ & $\begin{aligned} & \text { Sig } \\
\mathrm{z}= & -3.924 \\
\mathrm{p}= & 0.000\end{aligned}$ \\
\hline Winter & $\begin{array}{c}98.3 \pm 7.9 \\
(81-110) \\
\mathrm{n}=30\end{array}$ & $\begin{array}{c}112.4 \pm 6.3 \\
(100-126) \\
n=30\end{array}$ & - & & $\begin{array}{c}\quad \text { Sig } \\
z=-5.725 \\
p=0.000\end{array}$ & & \\
\hline Spring & $\begin{array}{c}98.7 \pm 8.4 \\
(80-114) \\
\mathrm{n}=29\end{array}$ & $\begin{array}{c}111.4 \pm 3.6 \\
(104-119) \\
n=30\end{array}$ & $\begin{array}{c}101.9 \pm 4.5 \\
(92-111) \\
\mathrm{n}=25\end{array}$ & 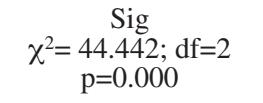 & $\begin{aligned} & \text { Sig } \\
z= & -5.668 \\
p= & 0.000\end{aligned}$ & $\begin{aligned} & \text { Sig } \\
& z=-5.675 \\
& p=0.000\end{aligned}$ & $\begin{array}{c}\text { Not Sig } \\
\mathrm{z}=-1.322 \\
\mathrm{p}=0.186\end{array}$ \\
\hline Summer & $\begin{array}{c}101.9 \pm 6.2 \\
(88.5-115) \\
n=27\end{array}$ & $\begin{array}{c}110.9 \pm 7.1 \\
(93.5-126) \\
\mathrm{n}=30\end{array}$ & - & & $\begin{array}{c}\quad \text { Sig } \\
\mathrm{z}=-4.438 \\
\mathrm{p}=0.000\end{array}$ & & \\
\hline Total & $\begin{array}{c}98.9 \pm 9.5 \\
(70-117) \\
n=116\end{array}$ & $\begin{array}{c}111.0 \pm 6.3 \\
(93-126) \\
n=120\end{array}$ & $\begin{array}{c}107.0 \pm 7.2 \\
(92-121) \\
\mathrm{n}=51\end{array}$ & $\chi^{2}=\underset{\substack{\mathrm{Sig} \\
\mathrm{p}=0.829 ; \mathrm{df}=2}}{0.000}$ & $\begin{aligned} & \text { Sig } \\
z= & -9.601 \\
p= & 0.000\end{aligned}$ & $\begin{aligned} & \text { Sig } \\
& z=-3.679 \\
& p=0.000\end{aligned}$ & $\begin{array}{c}\text { Sig } \\
\mathrm{z}=-4.903 \\
\mathrm{p}=0.000\end{array}$ \\
\hline $\begin{array}{l}\text { Significance } \\
\text { among seasons }\end{array}$ & $\begin{array}{c}\text { Not Sig } \\
\chi^{2}=3.413 ; \mathrm{df}=3 \\
\mathrm{p}=0.332\end{array}$ & $\begin{array}{c}\text { Not Sig } \\
\chi^{2}=1.423 ; \mathrm{df}=3 \\
\mathrm{p}=0.700\end{array}$ & $\begin{array}{c}\quad \text { Sig } \\
z=-5.146 \\
p=0.000\end{array}$ & & & & \\
\hline
\end{tabular}

TABLE 2. - Prevalence and mean intensity of Anisakis larva infection in Aphanopus carbo from the studied regions: significance of intensity differences among regions estimated by the Kruskal-Wallis ( $\left.\chi^{2} ; \mathrm{df} ; \mathrm{p}\right)$ or Mann-Whitney (z; p) test (Sig, significantly different).

\begin{tabular}{|c|c|c|c|c|c|c|c|}
\hline & \multirow[t]{2}{*}{ Sesimbra } & \multirow[t]{2}{*}{ Madeira } & \multirow[t]{2}{*}{ Azores } & \multirow{2}{*}{$\begin{array}{c}\text { Significance } \\
\text { among the } 3 \text { regions }\end{array}$} & \multicolumn{3}{|c|}{ Significance between regions } \\
\hline & & & & & Ses/Mad & $\mathrm{Mad} / \mathrm{Az}$ & Ses/Az \\
\hline $\begin{array}{l}\text { Prevalence }(\%) \\
\text { (number of fish examined) }\end{array}$ & $\begin{array}{c}100 \\
(116)\end{array}$ & $\begin{array}{l}100 \\
(120)\end{array}$ & $\begin{array}{l}100 \\
(51)\end{array}$ & & & & \\
\hline $\begin{array}{l}\text { Mean Intensity } \pm \text { s.d. } \\
\text { (minimum-maximum) } \\
\text { (number of fish infected) }\end{array}$ & $\begin{array}{c}154.2 \pm 253.2 \\
(12-1904) \\
(116)\end{array}$ & $\begin{array}{l}253.9 \pm 219.6 \\
(13-1128) \\
(120)\end{array}$ & $\begin{array}{c}53.7 \pm 26.7 \\
(13-144) \\
(51)\end{array}$ & $\begin{array}{c}\mathrm{Sig} \\
\chi^{2}=92.811 ; \mathrm{df}=2 \\
\mathrm{p}=0.000\end{array}$ & $\begin{aligned} & \mathrm{Sig} \\
\mathrm{z}= & -5.796 \\
\mathrm{p}= & 0.000\end{aligned}$ & $\begin{aligned} & \quad \text { Sig } \\
& z=-8.750 \\
& p=0.000\end{aligned}$ & $\begin{aligned} & \text { Sig } \\
& z=-5.871 \\
& p=0.000\end{aligned}$ \\
\hline
\end{tabular}

All the fish examined in the present study were infected (prevalence $=100 \%$ ), but significantly different intensities were found in the 3 regions. Madeira showed the highest value and the Azores the lowest (Table 2).

The analysis of intensity related to host length (Table 3) showed significant positive correlations for Madeira and Sesimbra, and significant negative correlation for the Azores. When the correlation analysis was carried out for each season (not shown in tables), significant positive correlations were again found for Sesimbra (in autumn, winter and summer) and Madeira (in autumn and summer), and no significant negative correlations were found. The comparison among intensities from the 3 regions for each length class again showed the highest and lowest intensity values in specimens from Madeira and the Azores, respectively (Table 3).
The seasonal analysis (Table 4) showed that intensity of the infection is significantly different throughout the year in the 3 regions. Summer (or spring in the Azores) is the season with the highest values, and winter (or autumn in Azores) is the one with the lowest. For each season, the highest and lowest intensity values were found in specimens from Madeira and the Azores, respectively.

\section{DISCUSSION}

The identification to species level of the nematodes infecting A. carbo is only possible using genetic molecular methodologies. The existence of two main clades was demonstrated by genetic studies. They included species showing Type I and Type II larval stages respectively that were closed in relation 
TABLE 3. - Intensity of Anisakis larvae infection in Aphanopus carbo according to the host length: correlation between intensity and host length estimated by the Spearman coefficient $(r ; n ; p)$ and significance of intensity differences among regions in each length class estimated by the Kruskal-Wallis $\left(\chi^{2} ; \mathrm{df} ; \mathrm{p}\right)$ or Mann-Whitney ( $\left.\mathrm{z} ; \mathrm{p}\right)$ test (Sig, significantly different or correlated).

\begin{tabular}{|c|c|c|c|c|c|c|c|}
\hline \multirow[b]{2}{*}{ Host length $(\mathrm{cm})$} & \multicolumn{3}{|c|}{$\begin{array}{l}\text { Mean Intensity } \pm \text { s.d. } \\
\text { (minimum-maximum) } \\
\text { (number of fish infected) }\end{array}$} & \multirow[t]{2}{*}{$\begin{array}{c}\text { Significance } \\
\text { among the } 3 \text { regions }\end{array}$} & \multicolumn{3}{|c|}{ Significance between regions } \\
\hline & Sesimbra & Madeira & Azores & & Ses/Mad & $\mathrm{Mad} / \mathrm{Az}$ & $\mathrm{Ses} / \mathrm{Az}$ \\
\hline$<90.0$ & $\begin{array}{l}66.9 \pm 49.9 \\
(20-204) \\
(22)\end{array}$ & - & - & - & & & \\
\hline $90.0-99.9$ & $\begin{array}{l}97.7 \pm 56.2 \\
(12-222) \\
(29)\end{array}$ & $\begin{array}{c}120.5 \pm 55.7 \\
(45-190) \\
(6)\end{array}$ & $\begin{array}{l}74.6 \pm 22.4 \\
(52-112) \\
(8)\end{array}$ & $\begin{array}{c}\text { Not Sig } \\
\chi^{2}=1.537 ; \mathrm{df}=2 \\
\mathrm{p}=0.464\end{array}$ & & & \\
\hline $100.0-109.9$ & $\begin{array}{c}215.3 \pm 353.9 \\
(16-1904) \\
(51)\end{array}$ & $\begin{array}{c}246.9 \pm 256.9 \\
(13-1128) \\
(38)\end{array}$ & $\begin{array}{l}55.7 \pm 28.1 \\
(13-144) \\
(25)\end{array}$ & $\begin{array}{c}\text { Sig } \\
\chi^{2}=31.826 ; \mathrm{df}=2 \\
\mathrm{p}=0.000\end{array}$ & $\begin{array}{c}\text { Not Sig } \\
\mathrm{z}=-1.174 \\
\mathrm{p}=0.240\end{array}$ & $\begin{aligned} & \text { Sig } \\
\mathrm{z}= & -4.897 \\
\mathrm{p}= & 0.000\end{aligned}$ & $\begin{aligned} & \text { Sig } \\
& \mathrm{z}=-5.130 \\
& \mathrm{p}=0.000\end{aligned}$ \\
\hline $110.0-119.9$ & $\begin{array}{c}185.2 \pm 197.2 \\
(38-813) \\
(14)\end{array}$ & $\begin{array}{l}251.6 \pm 181.9 \\
(52-913) \\
(67)\end{array}$ & $\begin{array}{l}41.7 \pm 14.8 \\
(23-82) \\
(15)\end{array}$ & 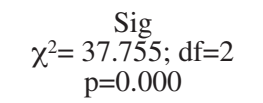 & $\begin{array}{c}\text { Not Sig } \\
\mathrm{z}=-1.892 \\
\mathrm{p}=0.058\end{array}$ & $\begin{aligned} & \text { Sig } \\
\mathrm{z}= & -5.895 \\
\mathrm{p}= & 0.000\end{aligned}$ & $\begin{array}{c}\text { Sig } \\
\mathrm{z}=-4.126 \\
\mathrm{p}=0.000\end{array}$ \\
\hline$\geq 119.9$ & - & $\begin{array}{l}389.7 \pm 320.6 \\
(41-1116) \\
(9)\end{array}$ & $\begin{array}{l}41.0 \pm 44.2 \\
(13-92) \\
(3)\end{array}$ & & & $\begin{array}{c}\quad \text { Sig } \\
\mathrm{z}=-2.311 \\
\mathrm{p}=0.021\end{array}$ & \\
\hline $\begin{array}{l}\text { Correlation } \\
\text { between intensity } \\
\text { and host length }\end{array}$ & $\begin{array}{c}\mathrm{Sig} \\
\mathrm{r}=0.451 ; \mathrm{n}=116 \\
\mathrm{p}=0.000\end{array}$ & $\begin{array}{c}\mathrm{Sig} \\
\mathrm{r}=0.198 ; \mathrm{n}=120 \\
\mathrm{p}=0.030\end{array}$ & $\begin{array}{c}\mathrm{Sig} \\
\mathrm{r}=-0.428 ; \mathrm{n}=51 \\
\mathrm{p}=0.002\end{array}$ & & & & \\
\hline
\end{tabular}

TABLE 4. - Intensity of Anisakis larvae infection in Aphanopus carbo according to the season of the year: significance of intensity differences among seasons and regions estimated by the Kruskal-Wallis $\left(\chi^{2} ; \mathrm{df} ; \mathrm{p}\right)$ or Mann-Whitney ( $\left.\mathrm{z} ; \mathrm{p}\right)$ test (Sig, significantly different).

\begin{tabular}{|c|c|c|c|c|c|c|c|}
\hline \multirow{2}{*}{$\begin{array}{l}\text { Sampling } \\
\text { Season }\end{array}$} & \multicolumn{3}{|c|}{$\begin{array}{l}\text { Mean Intensity } \pm \text { s.d. } \\
\text { (minimum-maximum) } \\
\text { (number of fish infected) }\end{array}$} & \multirow[t]{2}{*}{$\begin{array}{c}\text { Significance among } \\
\text { the } 3 \text { regions }\end{array}$} & \multicolumn{3}{|c|}{ Significance between regions } \\
\hline & Sesimbra & Madeira & Azores & & Ses/Mad & $\mathrm{Mad} / \mathrm{Az}$ & Ses/Az \\
\hline Autumn & $\begin{array}{c}112.6 \pm 91.4 \\
(16-390) \\
(30)\end{array}$ & $\begin{array}{c}173.3 \pm 159.7 \\
(13-913) \\
(30)\end{array}$ & $\begin{array}{l}42.6 \pm 18.8 \\
(13-92) \\
(26)\end{array}$ & $\begin{array}{c}\text { Sig } \\
\chi^{2}=29.264 ; \mathrm{df}=2 \\
\mathrm{p}=0.000\end{array}$ & $\begin{aligned} & \text { Sig } \\
\mathrm{z}= & -2.085 \\
\mathrm{p}= & 0.037\end{aligned}$ & $\begin{aligned} & \text { Sig } \\
\mathrm{z}= & -5.365 \\
\mathrm{p}= & 0.000\end{aligned}$ & $\begin{array}{c}\text { Sig } \\
\mathrm{z}=-3.353 \\
\mathrm{p}=0.001\end{array}$ \\
\hline Winter & $\begin{array}{c}98.3 \pm 74.9 \\
(12-367) \\
(30)\end{array}$ & $\begin{array}{c}159.4 \pm 95.2 \\
(41-400) \\
(30)\end{array}$ & - & - & $\begin{aligned} & \text { Sig } \\
z & =-3.342 \\
p & =0.001\end{aligned}$ & - & - \\
\hline Spring & $\begin{array}{l}128.4 \pm 142.8 \\
(22-813) \\
(29)\end{array}$ & $\begin{array}{c}244.9 \pm 162.5 \\
(43-638) \\
(30)\end{array}$ & $\begin{array}{l}65.2 \pm 29.2 \\
(13-144) \\
(25)\end{array}$ & $\chi^{2}=\underset{\substack{\mathrm{Sig} \\
\mathrm{p}=0.106 ; \mathrm{df}=2}}{ }$ & $\begin{aligned} & \text { Sig } \\
\mathrm{z}= & -3.480 \\
\mathrm{p}= & 0.001\end{aligned}$ & $\begin{array}{c}\text { Sig } \\
\mathrm{z}=-4.945 \\
\mathrm{p}=0.000\end{array}$ & $\begin{array}{c}\text { Sig } \\
\mathrm{z}=-2.707 \\
\mathrm{p}=0.007\end{array}$ \\
\hline Summer & $\begin{array}{l}290.1 \pm 469.6 \\
(23-1904) \\
(27)\end{array}$ & $\begin{array}{c}437.9 \pm 292.9 \\
(41-1128) \\
(30)\end{array}$ & & & $\begin{aligned} & \text { Sig } \\
z= & -3.620 \\
p= & 0.000\end{aligned}$ & & \\
\hline $\begin{array}{l}\text { Significance } \\
\text { among seasons }\end{array}$ & $\begin{array}{c}\text { Sig } \\
\chi^{2}=12.361 \\
\mathrm{df}=3 ; p=0.006\end{array}$ & $\begin{array}{c}\text { Sig } \\
\chi^{2}=28.653 \\
\mathrm{df}=3 ; \mathrm{p}=0.000\end{array}$ & $\begin{aligned} & \text { Sig } \\
z= & -3.016 \\
p= & 0.003\end{aligned}$ & & & & \\
\hline
\end{tabular}

to their definitive hosts, and presented different geographical distributions (see Mattiucci and Nascetti 2006, 2008). The presence of Type I and Type II larvae and preliminary results obtained by the authors of this paper (Saraiva et al., 2007) showed that the larvae collected in this study belong to several Anisakis species from the two groups (Anisakis simplex s.s. and A. ziphidarum and Anisakis sp., Type I larvae; A. physeteris, A. brevispiculata and A. paggiae, Type II larvae).

The high prevalence and intensity of infestation by Anisakis larvae observed in A. carbo are in accordance with previous reports (Costa et al., 1996, 2003; Santos et al., 2009). They can be explained 
by the predatory voracity of this fish, which probably acquires the infection by feeding on infected cephalopods and fish. Cephalopods and fish, namely Scomber scombrus and Micromesistius poutassou, are noted as the main food items of $A$. carbo (Froese and Pauly, 2008) and are well-known paratenic hosts of Anisakis (Abaunza et al., 1995; Abollo et al., 2001; Fernández et al., 2005; Cruz et al., 2007).

The different intensities obtained in the three regions must be analysed carefully because significant differences in the host length were observed among the regions. The increase in the infection level of Anisakis (measured by prevalence, intensity and abundance) with the age or length of the host reported for several fish species (Abaunza et al., 1995; Adroher et al., 1996; Manfredi et al., 2000; Valero et al., 2000; Fernández et al., 2005; Cruz et al., 2007) has often been explained by the accumulation of the parasite throughout the host life and by the increased amount of food ingested by larger fish. In the present study this relationship between intensity and host length was found in specimens from Madeira and Sesimbra, as can be seen in the significant positive correlations that were found. As the sample from the Azores showed a high degree of heterogeneity (significant differences in host length between seasons) we cannot discriminate the influence of host length and seasonality on the intensity of infection in the overall sample. However, it must be stressed that the unexpected negative correlation found in specimens from the Azores in the overall sample disappeared when the analysis was carried out for each season.

Although the highest intensity value in Madeira can be partially attributed to host length, a consistent geographical effect in intensity levels is easily visible when the intensities among the three regions are compared for each host length class, with Madeira showing the highest levels and the Azores the lowest ones. The same geographical pattern was observed in each season. It would be interesting in future studies to compare the black scabbard fish diet in the three regions and the Anisakis infection levels of the preys, which may help to the explain the geographical differences observed in the present work.

A seasonal variation in intensity of infection was evident in samples from Sesimbra and Madeira, with the highest values in summer. In the Azores, sampling was possible only in two seasons and, as discussed above, it is not possible to discriminate the influence of seasonality from the influence of host length without further sampling. The highest intensity values obtained in summer from Sesimbra and Madeira suggest an increased recruitment of the parasite larvae in this season. Without additional data it is not possible to attribute this seasonality to an increase in abundance of infected preys, to the presence of preys more intensively infected, to a more active feeding in warmer months or, alternatively, to seasonal changes in diet. Varying degrees of seasonality have been reported for anisakid infections in several hosts from different geographical areas (Adroher et al., 1996; Stromes and Anderson, 2000; Valero et al., 2000; Cruz et al., 2005; Farjallah et al., 2006) and this has been attributed to some of the factors presented above.

Finally, the high levels of Anisakis larvae, especially in Madeira specimens, and the fact that parasite larvae were also observed in the muscle strongly suggest that the consumption of raw or undercooked black scabbardfish is a potential health hazard.

\section{ACKNOWLEDGEMENTS}

This study was partially supported by Fundação para a Ciência e Tecnologia (project POCTI/ CVT/46851/2002).

\section{REFERENCES}

Abaunza, P., B. Villamor and J.R. Pérez. - 1995. Infestation by larvae of Anisakis simplex (Nematoda: Ascaridata) in horse mackerel, Trachurus trachurus, and Atlantic mackerel, Scomber scombrus, in ICES Divisions VIIIb, VIIIc and Ixa (N-NW of Spain). Sci. Mar., 59 (3-4): 223-233.

Abollo, E., C. Gestal and S. Pascual. - 2001. Anisakis infestation in marine fish and cephalopods from Galician waters: an updated perspective. Parasitol. Res., 87(6): 492-499.

Adroher, F.J., A. Valero, J. Ruiz-Valero and L. Iglesias. - 1996. Larval anisakids (Nematoda: Ascaridoidea) in horse mackerel (Trachurus trachurus) from the fish market in Granada (Spain). Parasitol. Res., 82(3): 253-256.

Anderson, R.C. - 2000. Nematode Parasites of Vertebrates: their Development and Transmission. CABI Publishing, New York.

Berland, B. - 1961. Nematodes from some Norwegian marine fishes. Sarsia, 2(1): 1-50.

Bush, A.O., K.D. Lafferty, J.M. Lotz and A.W. Shostak. - 1997. Parasitology meets ecology on its own terms: Margolis et al. revisited. J. Parasitol., 83 (4): 575-583.

Costa, G., J.C. Eiras, J. Chubb, K. MacKenzie and B. Berland. 1996. Parasites of the black scabbard fish, Aphanopus carbo Lowe, 1839 from Madeira. Bull. Eur. Ass. Fish Pathol., 16(1); 13-16.

Costa, G., T. Pontes, S. Mattiucci and S. D’Amélio. - 2003. The occurrence and infection dynamics of Anisakis larvae in the black-scabbard fish, Aphanopus carbo, chub mackerel, Scomber japonicus, and oceanic horse mackerel, Trachurus picturatus from Madeira, Portugal. J. Helminthol., 77(2): 163-166.

Cruz, C., A. Vaz and A. Saraiva. - 2005. Larval anisakids from horse mackerel in Portugal. Helminthologia, 42(1): 3-7.

Cruz, C., C. Barbosa and A. Saraiva. - 2007. Distribution of larval anisakids in blue whiting off Portuguese fish market. Helminth- 
ologia, 44(1): 21-24.

Farjallah, S., B.B. Slimane, H. Blel, N. Amor and K. Said. - 2006. Anisakid parasites of two forkbeards (Phycis blennoides and Phyces phyces) from the eastern Mediterranean coasts in Tunisia. Parasitol. Res., 100(1): 11-17.

Fernández, M., F.J. Aznar, F.E. Montero and J.A. Raga. - 2005. Endoparasites of the blue whiting, Micromesistius poutassou from north-west Spain. J. Helminthol., 79(1): 15-21.

Froese, R. and D. Pauly. - 2008. Fish Base World Wide Web electronic publication.www.fishbase.org, version (04/2008)

Grabda, J. - 1991. Marine fish parasitology. An outline. Polish Scientific Publishers, Warszawa.

Klimpel, S., E. Kellermanns and H.W. Palm - 2008. The role of pelagic swarm fish (Myctophidae: Teleostei) in the oceanic life cycle of Anisakis sibling species at Mid-Atlantic Ridge, Central Atlantic. Parasitol Res., 104 (1): 43-53.

Manfredi, M.T., G. Crosa, P. Galli, and S. Ganduglia. - 2000. Distribution of Anisakis simplex in fish caught in the Ligurian Sea. Parasitol. Res., 86(7): 551-553.

Mattiucci, S. and G. Nascetti. - 2006. Molecular systematics, phylogeny and ecology of anisakid nematodes of the genus Anisakis Dujardin, 1845: an update. Parasite, 13(2): 99-113.

Mattiucci, S. and G. Nascetti. - 2008. Advances and trends in the molecular systematics of anisakid nematodes with implications for their evolutionary ecology and host-parasite co-evolutionary process. Advances in Parasitology, 66: 47-148.

Moravec, F. - 1994. Parasitic nematodes of freshwater fishes of Europe. Academia, Prague and Kluwer Academic Publishers, Dordrecht.

Santos, M.J., A. Saraiva, C. Cruz, J.C. Eiras, M. Hermida, C. Ventura and J.P. Soares. - 2009. Use of parasites as biological tags in stock identification of black scabbardfish Aphanopus carbo Lowe, 1839 (Osteichthyes: Trichiuridae) from Portuguese waters. Sci. Mar., 73S2: 55-62.
Saraiva, A., A. Faranda, S. Damiano, M. Hermida, M.J. Santos, C.H. Ventura, J.P. Soares, C. Cruz, J.C. Eiras and S. Mattiucci - 2007. Six species of Anisakis (Nematoda: Anisakidae) parasites of the black scabbardfish, Aphanopus carbo from NE Atlantic waters: genetic markers and fish biology. Parassitologia, 49(2): 229.

Siegel, S. and N.J. Castellan, Jr. - 1989. Nonparametric statistics for the behavioral sciences. McGraw-Hill International Editions, New York.

Silva, M.E.R. and J.C. Eiras. - 2003. Occurrence of Anisakis sp. in fishes off the Portuguese West Coast and evaluation of its zoonotic potential. Bull. Eur. Ass. Fish Pathol., 23(1): 13-17.

Smith, J.W. and R. Wootten. - 1975. Experimental studies on the migration of Anisakis sp. larvae (Nematoda: Ascaridida) into the flesh of herring, Clupea harengus L. Int. J. Parasitol., 5(2): 133-136.

Stromnes, E. and K. Andersen. - 2000. "Spring rise" of whaleworm (Anisakis simplex; Nematoda, Ascaridoidea) third-stage larvae in some fish species from Norwegian waters. Parasitol. Res. 86(8): 619-624.

Ubeira, F.M., B. Valinas, S. Lorenzo, R. Iglesias, A. Figueiras and R. Garcia-Villaescusa. - 2000. Anisaquiosis y alergia. Un estudio seroepidemiológico en la Comunidad Autónoma Gallega. Documentos Técnicos de Salud Pública, Serie B, $n^{\circ} 24$. Ed. Conselleria de Sanidade e Servicios Sociais, Xunta de Galicia, España.

Valero, A., J. Martín-Sánchez, E. Reyes-Muelas and F.J. Adroher. 2000. Larval anisakids parasitising the blue whiting, Micromesistius poutassou, from Motril Bay in the Mediterranean region of southern Spain. J. Helminthol., 74(4): 361-364.

Scient. ed.: L.S. Gordo.

Received December 12, 2008. Accepted September 7, 2009.

Published online December 22, 2009. 